\author{
Review Article
}

\title{
A ROLE OF UDUMBARA KSHEER SUTRA IN ANO RECTAL FISTULA: AN AYURVEDIC REVIEW
}

\section{Anup Kumar ${ }^{*}$, Suman Yadav ${ }^{2}$, Ashutosh Kumar Yadav ${ }^{3}$}

${ }^{*}$ PG Scholar, ${ }^{2}$ Reader and Head of Dept. of Shalya Tantra, ${ }^{3}$ Reader, Dept. of Rachana Sharira, Govt. Ayurvedic College and Hospital, Varanasi, India.

\begin{tabular}{l}
\hline Article info \\
Article History: \\
Received: 21-11-2021 \\
Revised: 10-12-2021 \\
Accepted: 29-12-2021 \\
\hline KEYWORDS: \\
Ashtamahagad, \\
Bhagandara, \\
Fistula-in-ano, \\
Udumbara \\
ksheersutra, \\
Apamarga Kshar \\
Sutra.
\end{tabular}

\begin{abstract}
Acharya Sushrut has involved Bhagandara among the Ashtamahagad (8 dreadful diseases). At first it is present as Pidika (boil/abscess) in Apakwa (non-suppurated) state, become Bhagandara when it becomes Pakwa (suppurated). As defined in modern science, it is associated with fistula in ano. An anal fistula is an abnormal track having an external opening in the perianal region and internal opening in the anal canal and/or rectum.

Ayurveda has a special approach to fistula management. All anal fistulas counter well to different forms of Kshar and Ksheer Sutra therapy. They are nothing but the medicated seton. The Ksheer sutra mechanical and chemical action of drugs coated on the thread work jointly to cut, cure, drain and clean the fistulous tract, thereby promoting track/wound healing. Though Bhrihattrayi, (chief three texts of Ayurveda) stated the use of Kshar Sutra, there is no proper description of their method of preparation. In eleventh century, Chakrapani Datta mentioned the preparation method of Ksheer sutra in his book Chakradatta for the first time which is indicated in Arsha and Bhagandara.

Apamarga Kshar Sutra is the standard Kshar Sutra, and but it has some disadvantages. A variety of other Kshar Sutra, as well as Ksheer Sutra, have been prepared to resolve these inconveniences of Apamarga Kshar Sutra. One of them is Udumbara Ksheer Sutra which was founded by Prof. P.J Deshpande and M.K Jalan in 1984. Udumbara is one among the Nyagradhadi Gana Dravya mentioned by Acharya Sushrut. He described in Bhagandara Chikitsa that the Nyagradhadi Gana Dravyas are Bhagandaranashak.
\end{abstract}

\section{INTRODUCTION}

Bhagandara ${ }^{[1]}$ is a chronic purulent disease usually affects Bhaga (pelvic, perianal region and around anus) and it proceeds initially with an abscess ${ }^{[2]}$. The pathological process of different types of Bhagandara are studied and determined that different types of Bhagandara affect the surrounding tissues of ano-rectal region with varying course of tract and discharge of pus, fecal matter, urine and other by products through the sinus are the common clinical features ${ }^{[3]}$. Hence, Bhagandara can be defined as a suppurative secondary ulcerative manifestation to an eruption at ano-rectal, pelvic-rectal or perianal region which can be simulated with fistula-in-ano[4].

\begin{tabular}{|l|l|}
\hline \multicolumn{3}{|c|}{ Access this article online } \\
\hline Quick Response Code & \begin{tabular}{l} 
https://doi.org/10.47070/ijapr.v10i1.2173 \\
\hline
\end{tabular} \\
\hline
\end{tabular}

A Saririka vranasopha following the course of shat Kriyakala, Bhagandara initial exposures with a localized inflammatory lesion called Pidika which subsequently undertakes three important pathological stages Ama, Pachyamana and Pakwa avastha. Bhagandara has been described as five types ${ }^{[5]}$.
i. Vatika bhagandara (Sataponaka)
ii. Paittika bhagandara (Ustragreeva)
iii. Kaphaja bhagandara (Parisravi)
iv. Sannipataja bhagandara (Sambukavarta)
v. Agantuja bhagandara (Unmargi)

Now-a-days, management of Bhagandara by the use of Ksharasutra ${ }^{[6-7]}$ grew popularity due to least reoccurrence.

The anal fistula is an infamous disease due to its recurrence rate. Bhagandara is varyingly defined as a tear, ulcer or boil at Bhaga within 2 finger circumferences of it, causing painful abscess when opened is called. The word 'Bhagandara' has got two components- Bhaga and Darana. Bhaga means perianal region and Darana means to tear. Acharya 
Sushruta has promoted various types of operations in Sushruta Samhita.

He has promoted Kshara Sutra treatment due to probability of recurrence after surgery. Sushruta describes different kinds of Kshara like Palasa, Kadali. The most remarkable is Udumbara (Ficus Glomerata) among them. The present treatment modality Udumbara Ksheer Sutra has been found effective due to its action of proper drainage of pus from the fistula that leads to a proper healing and as adjuvant therapy by avoiding recurrence in Fistula in ano.

Subsequently Dr Subhashchandra Varshney carried out a study titled, Management of Fistula in ano by Udumbara ksheer sutra around 800 participants were chosen, and significant results were obtained[8]. Its use is in vogue from last many years but yet not standardized. As standardization of any medical drug or device or any other product is mandatory, so to maintain its quality level depending on different parameter there is a need for the standardization of the Udumbara ksheer sutra too. The present study is an attempt to standardize Udumbara ksheer sutra and examine the efficacy of standardized Udumbara ksheer sutra over standard Apamarga kshar sutra. This study is also proposed to evaluate antimicrobial activity and self-life period of Udumbara ksheer sutra.

\section{Preparation of Udumbara Ksheer Sutra}

Chakrapani Dutta was the first person to mention the method of preparation with its indication in Bhagandara (fistula in ano) and Arsha [9] (hemorrhoid). He described method of preparation as smearing a thread repeatedly in latex of Snuhi (Euphorbia neriifolia) and Haridra (turmeric) powder [10].

भावितं रजनी चूर्ण स्तुहीक्षीरे पुनः पुनः । बन्धनात् सुहढ़ सूत्रं भिनत्यर्शो भगन्दरम् ॥ चक्रदत्त अर्श चिकित्सा 5/148) (भै.र.अर्शोधिकार चिकित्सा 9/271) ${ }^{[11]}$

\section{Materials and Method}

1. Udumbara ksheer-Collects in early morning in sterile container.

2. Haridra powder

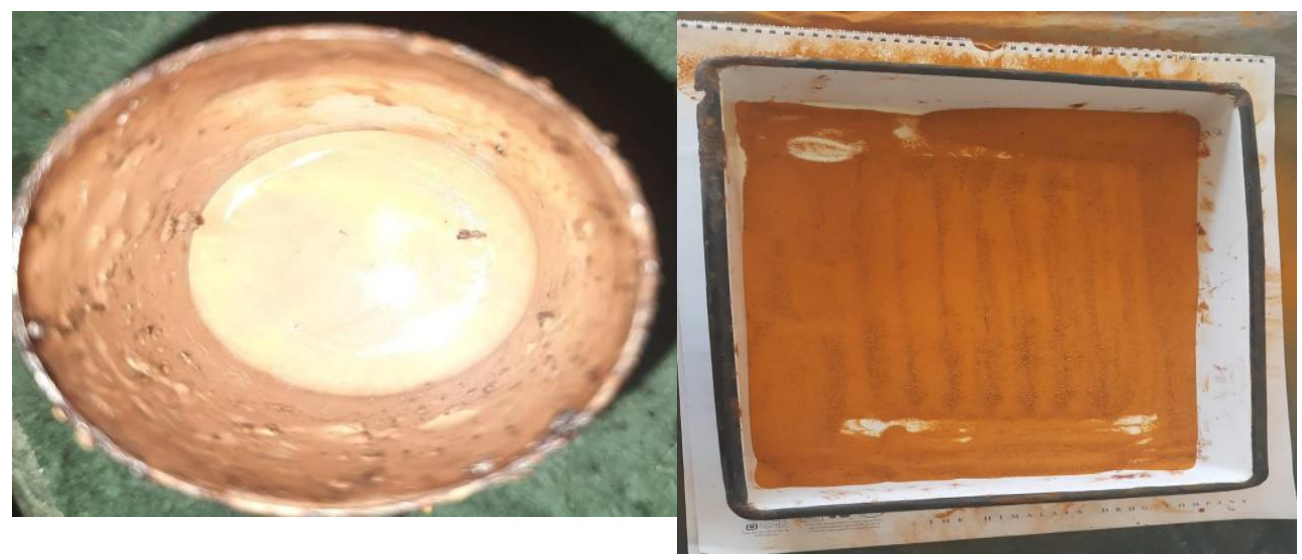

Figure 1: Udumbara ksheer and Haridra powder

According to Acharya chakrapani made this Ksheer sutra[12].11 coatings of Udumbara ksheer and 03 coating of Haridra was made on the thread. Every coatings was used in fresh Ksheer. The pH of the thread is 8.5.

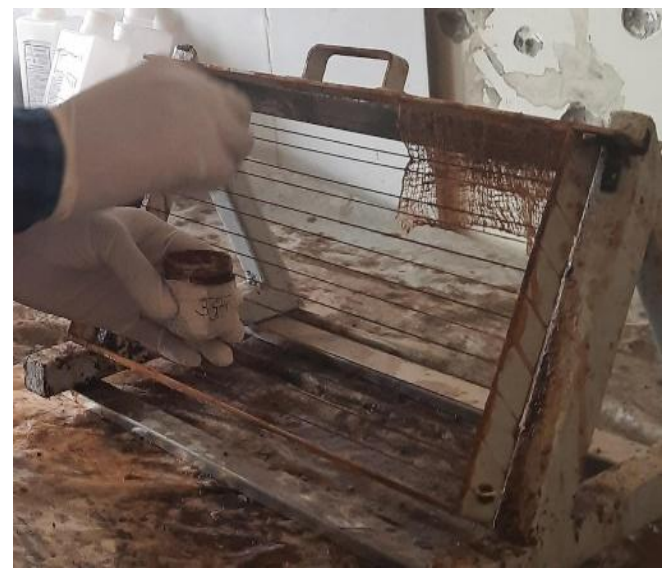

Figure 2: Udumbara Ksheer Coating

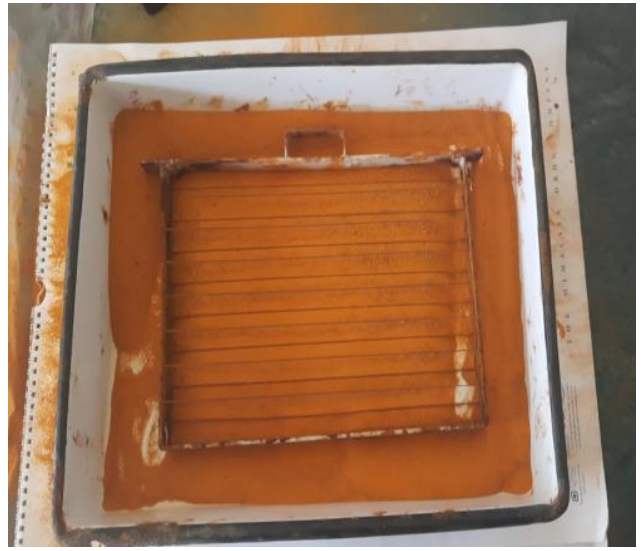

Figure 3: Haridra coating 


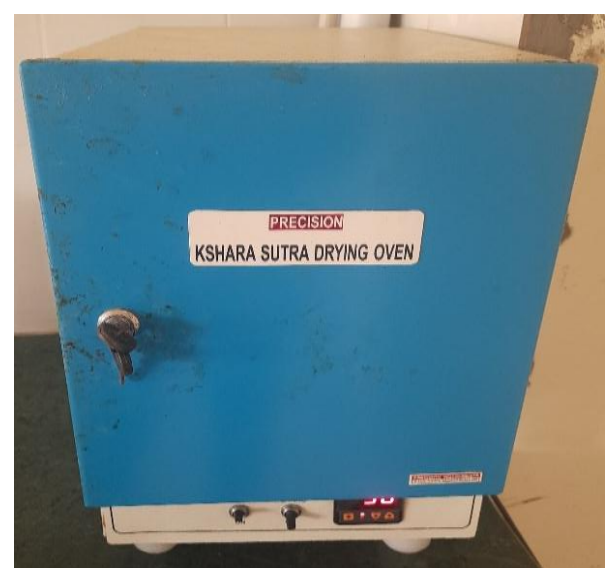

Figure 4: After coating of Ksheer sutra will be placed in Kshara sutra drying oven

\section{Primary Outcomes}

Udumbara Ksheer Sutra will be useful for the management of Bhagandaraa which will reduce pain, itching, discharge and burning sensation and at the same time it will cut and heal the fistulous tract. This study also includes analytical standardization of Udumbara Ksheer Sutra which will set a consistent parameter for quality assurance of Udumbara Ksheer Sutra along with applied clinical as well as professional aspect.

The Udumbara ksheer Sutra acts by its alkaline nature which promotes cutting and healing of fistulous tract.

\section{Secondary Outcomes}

As the ingredient for the chosen intervention is easily available all over India hence this study will contribute to cost effective, safe, readily available, simple preparation and a good remedy for managing Shalya tantra.

Use of Udumbara ksheer Sutra is found to be very effective in avoiding recurrence. There is no recurrence after one year.

\section{Standardization of Udumbara Ksheer Sutra[13,14]}

Standardization will be done by organoleptic and physicochemical testing of Udumbara Ksheer and Udumbara Ksheer Sutra and then the standards of Ksheer Sutra will be determined. It will be conducted at Govt. Ayurvedic College and Hospital Varanasi.

The analysis is conducted in three stages

i. Raw material

ii. Intermediate (in the process) product

iii. Final product

Various characteristics of an ideal Ksheer sutra based upon these analyses are as follows:

$\mathrm{PH}=10.1$

Length: $30 \pm 1 \mathrm{~cm}$

Diameter: $1.9 \mathrm{~mm}$

Min. breaking load: $5.83 \mathrm{~kg}$

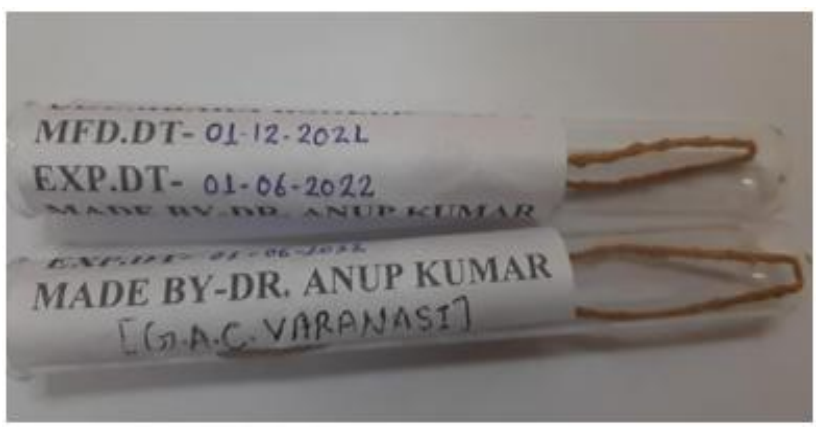

Figure 5: After drying Ksheer sutra will be packed in sterile tube

Weight of coating: 0.83gm

Thickness of thread after coating: $210+0.11 \mathrm{~mm}$

\section{Sterilization Sealing and Preservation}

For sterilization we kept Ksheer Sutra in Ksharsutra cabinet under expose of ultra violet rays. After sterilization Ksheer sutra kept in glass tubes and sealed with cork finally labeled for ready to use.

\section{Recent advances in Ksheer sutra}

Although the standard Apamarga[15] Ksharasutra is used successfully in the management of various surgical diseases, the difficulties in its preparation and application are worth noting. These problems have put necessity of further modifications. One of the essential components of above thread is Snuhi latex. Latex creates many problems during preparation of the thread. A very little amount of latex collected after the incision of the stem. It coagulates if not used early. Collection becomes more it is difficult to collect latex in summer, so preparation of Kshar sutra is possible only in limited seasons. Another disadvantage is severe pain felt by the patients during the application of thread. In few cases, the intensity of pain is so severe that the patients discontinue the therapy, allergic reactions are also noted. To overcome these problems, several researches have been carried out searching for the drugs having better actions and acceptability than that of Snuhi latex and Apamarga kshara and different types of Kshara sutra were prepared. By keeping above in mind we prepare Udumbara ksheer sutra for complication free treatment of fistula in ano.

\section{DISCUSSION}

Ayurveda has been evidenced successful in managing several diseases and chronic conditions.[1629] Studies on Fistula in ano were described by Chandak et al[30] and Lamture et al.[31] Studies from the global burden of disease are available.[32-34] Bhagandara is accomplished by various modern surgical and medical 
treatments, but all therapies have limitations and the chance of recurrence. Complication free treatment of Bhagandara i.e., Ksheer Sutra is a minimal invasive para surgical measure capable of performing excision or Chhedan; under its mechanical pressure and phytochemical cauterization. Although the standard Apamarga Kshar Sutra is used successfully, the difficulties in its preparation and application are worth noting. Various researches have been conducted on this Sutra but the product has not yet been fully standardized and not comparatively evaluated with Apamarga Kshar Sutra. With a few to lay down standards for identity and quality control of the constituent as well as the finished product, standardization is the necessity.

\section{CONCLUSION}

So, this study is undertaken to standardize Udumbara Ksheer Sutra and also evaluate its efficacy in the management of Bhagandara as well as its comparative evaluation with the efficacy of Standard Apamarga Kshar Sutra in a systematic way. If Udumbara Ksheer Sutra proved to be more efficient in managing Bhagandara compared to Apamarga Kshar Sutra then it will provide more acceptable as well as convenient treatment and alternative to the conventional surgical methods. Moreover, if the duration of healing is found to be less compared to Apamarga Kshar Sutra, then this work will have significant value in treating Bhagandara with minimized therapeutic duration than the current duration.

\section{REFRENCES}

1. Susruta Samhita edited with Ayurveda - Tatatva Sandipika by Kaviraj Ambika Dutta Shastri, Vol. I, Reprint edition, Chp. 4/4, Varanasi; Chaukhambha Sanskrit Sansthan; 2005. p. 244.

2. S. Das, Text Book of Surgery, $3^{\text {rd }}$ edition, Calcutta: S. Das, Old Mayors' Curt; 2001. p. 131.

3. S. Das, Text Book of Surgery, $3^{\text {rd }}$ edition, Calcutta: S. Das, Old Mayors' Curt; 2001. p. 1053.

4. S. Das, Text Book of Surgery, $3^{\text {rd }}$ edition, Calcutta: S. Das, Old Mayors' Curt; 2001. p. 1052.

5. Susruta Samhita edited with Ayurveda - TatatvaSandipika by Kaviraj Ambika Dutta Shastri, Vol. I, Reprint edition, Chp. 4/3, Varanasi; Chaukhambha Sanskrit Sansthan; 2005. p. 244.

6. Agnivesh, Kashinath Shastri, Gorakhnath Chaturvedi, Vol. II, Re edition, Chp. 12/97, Varanasi; Chaukhambha Bharati Academy; 2004. p. 378.

7. Chakrpanidatta, Indradev Tripathi, Chakradutta, Re edition, Chp. 45/10, Varanasi; Chaukhambha Sanskrit Bhawan; 2011. p. 268.

8. Varshney SC, Chaukhande MS. Management of Fistula in ano by UdumbaraKshar Sutra. Sangyaharan Shodh 2011; 14 (2): 29- 33.
9. Sri Jagdishwar Prasad Tripathi commentary on Cakradatta of Chakkrapani, Nadi vrana Chikitsa, verse 11, Varanasi: Chaukhambha Sanskrit Series office; 2008.p.361.

10. Sri Jagdishwar Prasad Tripathi commentary on Cakradatta of Chakkrapani, Arsha Chikitsa, verse 148, Varanasi: Chaukhambha Sanskrit Series office; 2008.p.91.

11. Siddhiprada hindi commentary on Bhaisajya Ratnavali of Kaviraj Govind das Sen Arsha Chikitsa Chapter 9, verse 271, Varanasi: Chaukhambha Surbharati Prakashan; 2009.Page no.333.

12. Sri Jagdishwar Prasad Tripathi commentary on Cakradatta of Chakkrapani, Nadi vrana Chikitsa, verse 11, Varanasi: Chaukhambha Sanskrit Series office; 2008.p.361.

13. Sharma SK, Sharma KR, Singh Kulwant. Kshara Sutra therapy in fistula-in-ano and other anorectal disorders. New Delhi: Rashtriya Ayurved Vidyapeeth; 1994-1995. p.58.

14. Sharma SK, Sharma KR, Singh Kulwant, Kshara Sutra Therapy In Fistula-in-ano And Other AnoRectal Disorders New Delhi: Rashtriya Ayurved Vidyapeeth; 1994-1995. p.203

15. Atul Bharadwaj, Riju Agarwal, Manoj tanwar, Anoop kumar, clinical comparison of tympanic membrane perforation closure with trichloroacetic acid and apamarga kshara (Achyranthus Aspara Linn. Alkaline extract),Int J Ayu and Pharma Rcs, 2016; (1): 16-22

16. Bindalkar VS, Ade V, Deshmukh S. Ayurvedic Management of Kitibha Kushta w.r.t. Guttate Psoriasis- A Single Case Study. Inter J Ayu Med 2020; 11(3): 136-42.

17. Chandankar SB, Kuchewar V. Management of Vipadika through Ayurveda. Int J Ayu Med 2019; 10(1): 122-4.

18. Chavhan MH, Wajpeyi SM. Management of Dadru Kushta (Tinea corporis) through Ayurveda-A Case Study. Int J Ayu Med 2020; 11: 120-23.

19. Bhende SV, Parwe S. Ayurveda management of Mutrashmari with special respect to urolithiasis: A case study. J Indian Syst Med 2019; 7(3): 189.

20. Parwe SD, Nisargandha MA. Effect of Panchalavan churna with goghruta in malavstambha (constipation). World J Pharmaceu Res 2018; 7(16): 757-766.

21. Deshmukh NA, Ade V, Supare SS. Management of Kamala (Jaundice) through Ayurved-A Case Report. Int J Ayu Med 2017; 11(1): 128-30.

22. Gupta KR, Sawarkar G, Jadhav U. Critical appraisal of pipasa in chronic obstructive pulmonary disease. Int J Ayu Med 2019; 11(1): 44-9.

23. Gupta RK, Deogade M. A Critical Review on Ethnobotanical, Phytochemical and 
Pharmacological Investigations of Martynia annua Linn. Int J Ayu Med 2018; 9(3): 136-43.

24. Giri D, Wairagade S, Desai P, Agrawal A, Jha RK. Relation Between Prakriti and Stress Handling Capacity: An Observational Study. Int J Curr Res Rev 2020; 12(15): 103.

25. Kombe P, Kuchewar V. Evaluation of the effect of Kanchanar Guggul in sub-clinical hypothyroidism concerning Agnimandya. Int J Ayu Med 2019; 10(4): 310-6.

26. Sawarkar P, Sawarkar G. Peer-Assisted Learning of Procedural Skill in Basti Karma (Medicated Enema) A Pilot Study. Int J Ayu Med 2019; 10(4): 317-22.

27. Sawarkar P, Sawarkar G. Peer-Assisted Learning of Procedural Skill in Basti Karma (Medicated Enema) A Pilot Study. Int J Ayu Med 2019; 10(4): 317-22.

28. Wajpeyi SM. Analysis of Etiological Factors of Dyslipidemia-A Case Control Study. Int J Ayu Med 2020; 11(1): 92-7.

29. Zanwar AC, Wajpeyi SM. Management of Hepatitis B (Carrier stage) through Ayurved-A Case report. Int J Ayu Med 2019; 10(4): 342-4.
30. Chandak S, Niveditha S, Shinde S. Traumatic low fistula-in-ano. J Datta Meghe Inst Med Sci Uni 2019; 14(3): 256.

31. Lamture YR, Domkunti R, Rinait A, Padmawar M. Enterocutaneous Fistula In An Operated Case of Total Abdominal Hysterectomy: A Rare Case Report. J Crit Rev 2020; 7(8): 1085-8.

32. James SL, Castle CD, Dingels ZV, Fox JT, Hamilton EB, Liu Z, et al. Estimating global injuries morbidity and mortality: methods and data used in the Global Burden of Disease 2017 study. Inj Prev 2020; 26(1): i125-53.

33. Murray CJL, Abbafati C, Abbas KM, Abbasi M, Abbasi-Kangevari M, Abd-Allah F, et al. Five insights from the Global Burden of Disease Study 2019. Lancet 2020; 396 (10258): 1135-59.

34. Wang $\mathrm{H}$, Abbas KM, Abbasifard $\mathrm{M}$, AbbasiKangevari M, Abbastabar H, Abd-Allah F, et al. Global age-sex-specific fertility, mortality, healthy life expectancy (HALE), and population estimates in 204 countries and territories, 1950-2019: a comprehensive demographic analysis for the Global Burden of Disease Study 2019. Lancet 2020; 396(10258): 1160-203.

\section{Cite this article as:}

Anup Kumar, Suman Yadav, Ashutosh Kumar Yadav. A Role of Udumbara Ksheer Sutra in Ano Rectal Fistula: An Ayurvedic Review. International Journal of Ayurveda and Pharma Research. 2022;10(1):98-102.

https://doi.org/10.47070/ijapr.v10i1.2173

Source of support: Nil, Conflict of interest: None Declared

\section{*Address for correspondence Dr. Anup Kumar \\ P.G. Scholar, \\ Dept. of Shalya Tantra, \\ Govt. Ayurvedic College and \\ Hospital, Varanasi \\ Email: \\ dr.anupkumar1991@gmail.com \\ Mobile no. 8864990210}

Disclaimer: IJAPR is solely owned by Mahadev Publications - dedicated to publish quality research, while every effort has been taken to verify the accuracy of the content published in our Journal. IJAPR cannot accept any responsibility or liability for the articles content which are published. The views expressed in articles by our contributing authors are not necessarily those of IJAPR editor or editorial board members. 